\title{
АНАЛИЗ РИСКОВ СОТРУДНИЧЕСТВА ИРАНА, РОССИИ И ЕЕ СОЮЗНИКОВ "
}

\author{
(c) 2020 Бурцева К. Ю. \\ кандидат экономических наук, доцент Департамента бизнес-аналитики, \\ Финансовый университет при Правительстве Российской Федерации, Россия, Москва \\ E-mail: aksentiya@mail.ru
}

Долгосрочное сотрудничество России и Ирана позволит увеличить экономические, инвестиционные обмены между странами и поможет исламской республике повысить уровень экономики и жизни граждан, но данные процессы связаны с определенными в статье рисками, тормозящими развитие партнерских взаимовыгодных отношений. Анализ и идентификация рисков были осуществлены согласно предложенной в работе классификации стейкхолдеров. Выделены риски для Ирана, России, ЕАЭС, ЕС и США.

Статья подготовлена по результатам исследований, выполненных за счет средств по государственному заданию Финуниверситета

Ключевые слова: Россия, Иран, ЕАЭС, ЕС, США, сотрудничество, многостороннее партнерство, риски.

Россия, как крупная региональная страна, имеет около 500 миллиардов долларов товарооборота с миром и продолжает развивать сотрудничество с целью экономических и инвестиционных обменов, в свою очередь партнерство России с Ираном может помочь исламской республике повысить уровень экономики и жизни граждан. Взаимодействие государств уже осуществляется как на прямую, так и в рамках Евразийского экономического союза (ЕАЭС), образованного 1 января 2015 года и включающего Россию, Беларусь, Казахстан, Армению и Кыргызскую республику. Ключевыми целями ЕАЭС являются расширение сотрудничества и повышение экономической конкурентоспособности государств-членов, а также содействие стабильному развитию в целях повышения уровня их жизни.

Анализ рисков сотрудничества Ирана, России и ее союзников предложено провести на основе применения концепции заинтересованных сторон (стейкхолдеров) в развитии интеграционных процессов между ее участниками. Основные заинтересованные стороны были классифицированы на внешних и внутренних $[1,2]$. Среди внутренних выделены непосредственные участники соглашения, имеющие прямую заинтересованность в интеграции: Иран, Россия и союзники по ЕАЭС. Для них выделены потенциальные риски развития процессов сотрудниче-

ства в рамках экономического союза. Внешние стейкхолдеры были определены исходя из реальных рисков, возникающих для них в результате активизации интеграционных процессов ЕАЭС. Предложенная классификация стейкхолдеров, заинтересованных \незаинтересованных в сотрудничестве Ирана, России и ее союзников представлена на рисунке 1.

Представители стран участниц ЕАЭС подписали соглашение о сотрудничестве для ускорения организации международного транспортного коридора Север-Юг, который пройдет из России в Индию через Тегеран. Транзитный коридор Север-Юг - это самая короткая дорога смешанных перевозок, связывающая Индийский океан и Персидский залив через Иран и Россию с Северной Европой. Расчетная мощность коридора составляет около 20-30 млн. долларовых товаров в год, он позволяет сократить время и стоимость примерно на 30-40 процентов. Россия вложила в этот проект около $\$ 1,2$ млрд. долларов, Индия также вложила огромные средства. Но, как известно, проект затягивается из-за Ирана, иранцы еще не завершили строительство железной дороги на своей территории между Астарой и Рештом в Северном Иране.

У Ирана есть проблемы с финансовыми ресурсами для завершения этого проекта. В январе 2018 года на заседании иранского кабинета министров под председательством президента

\footnotetext{
* Статья подготовлена по результатам исследований, выполненных за счет средств по государственному заданию Финуниверситета
} 


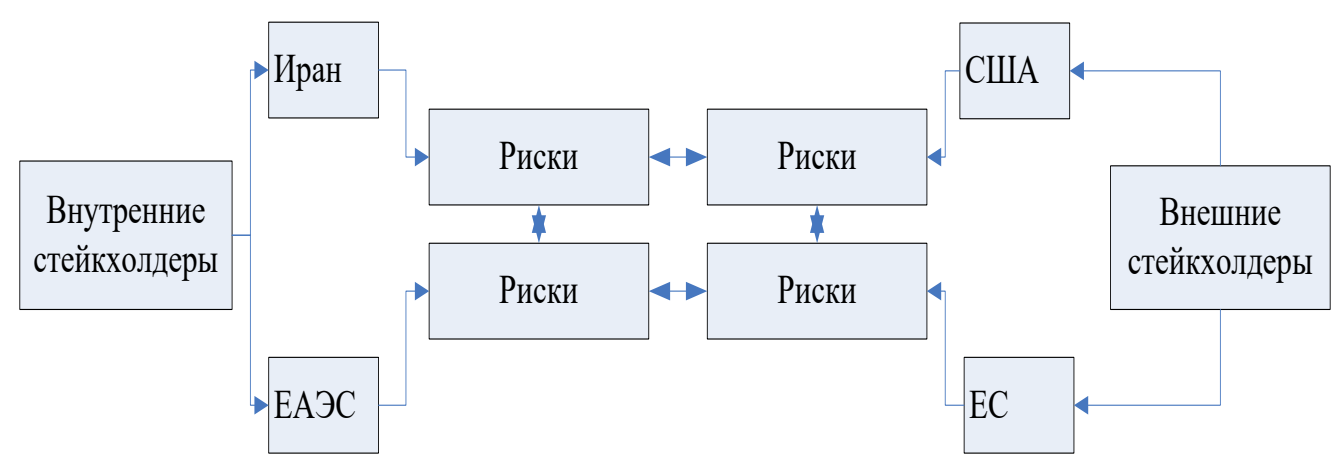

Рисунок 1. Классификация стейкхолдеров, заинтересованных $\$ незаинтересованных в сотрудничестве Ирана, России и ее союзников по ЕАЭС.

Х.Роухани была достигнута договоренность о получении от Азербайджана кредита в размеpe $\$ 500$ млн. на строительство железной дороги Рашт-Астара. Ирану было дано три года на строительство проекта и семь лет на возврат кредита. Ранее замминистра дорог и градостроительства А.Ноорзад заявил, что кредит будет выделяться под низкие процентные ставки - около 2,5 процента годовых. Но санкции против Ирана создают проблемы для строительства и для завершения транзитных проектов в других частях Ирана. Коридор Север-Юг призван соединить Северную Европу с Индией и Южной Азией и соединить железную дорогу в Иране, Азербайджане и России. Он дает Ирану возможность перевозить товары с западного побережья Индии в Иран Бендер Аббас и порта государств Центральной Азии и Россию. Это наилучший шанс для Ирана использовать этот проект для экспорта большего количества товаров с низкой транзитной платой, чтобы получить более экономичные и политические выгоды.

Финансовые проблемы не позволили Ирану завершить проект за два-три планируемых года, не смог он этого сделать и к концу прошлого года. Иран не в состоянии найти технологии и финансовые возможности, что влечет за собой риски невыполнения обязательств по завершению проекта.

Напряженные социальные отношения в Иране, повышение безработицы спровоцируют миграционные процессы, которые могут негативно отразиться на развитии интеграционных процессов.

Полноценное вступление Ирана в Евразийский экономический союз может значительно усилить его влияние, но навязать подчинённую роль Исламской Республике просто не получит- ся. Существует риск возникновения трений, а в перспективе - конфликтов с Россией и её союзником - Казахстаном.

У Евразийского экономического союза имеются недостатки и организационного характера: например, в этой организации нет органа контроля над соблюдением Таможенного кодекса. Также в ЕАЭС отсутствуют структуры, непосредственно отвечающие за модернизацию - ни как отдельный орган, ни как подразделение, например, в виде коллегии Евразийской экономической комиссии (ЕЭК); наука и техника, без коих никакое повышение конкурентоспособности национальных экономик априори невозможно, тоже обделены вниманием: если информационно-коммуникационными технологиями всё-таки заведует Департамент информационных технологий ЕЭК, то остальное будет передано в Фонд по делам экономического и научно-технического сотрудничества, который еще только предполагается создать.

Снижение таможенных пошлин или открытие рынков может негативно повлиять на внутреннее производство стран-участниц, чего участники соглашения стараются избежать. Наплыв дешевой продукции может спровоцировать риски массового банкротства промышленных и сельскохозяйственных предприятий в ЕАЭС.

Анализируя вызовы и перспективы развития бизнеса для стран ЕАЭС Р. Курбангулова выделила три категории возможных барьеров [3] (рисунок 2).

Иран находится под санкциями, которые влекут за собой огромное количество проблем. Иранская экономика пострадала от санкций, закрываются заводы, наблюдается высокий уровень безработицы и существуют риски ее 


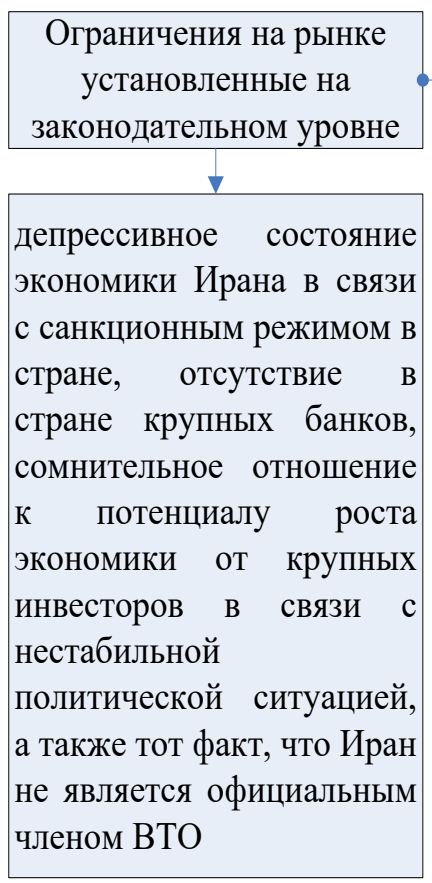

Рисунок 2. Возможные барьеры для развития бизнеса стран ЕАЭС повышения. Повышаются риски неуплаты заработной платы работникам. Иран ищет какой-то способ, чтобы преодолеть санкции. Но в краткосрочной перспективе значительно пострадают из-за санкций люди. Рабочие протестуют против правительства, требуя обратить внимание на их проблему и решить ее. Существует риск возрастания протестов в городах и крупных заводах в ближайшие месяцы и годы. Напряженные социальные отношения в стране негативно отразятся на развитии интеграционных процессов с ЕАЭС.

Иран ищет способ сыграть важную роль в регионе и специально пытается взять на себя роль в региональной организации, такой как Евразийский экономический союз. Использование национальных валют Ираном и Россией влечет определенные проблемы при экспорте и импорте товаров из обеих странах. Частный сектор сталкивается с проблемами при экспорте и импорте товаров из России в Иран или из Ирана в Россию. В обеих странах наблюдается потенциальное снижение тенденции создания торговли в долларах в экономических отношениях. Обе страны перед использованием собственных валют пытались решить возникающие пробле- мы, касающиеся бизнеса и частных компаний в обеих странах. Но страны приняли решение использовать свою национальную валюту в среднесрочной или долгосрочной перспективе.

Иран абсолютно необходим для партнерства между Россией и Китаем, как и в случае с Северной Кореей. Россия и Китай проявляют признаки того, что Иран находится в тесно скоординированной евразийской сфере влияния и любая атака на Иран будет считаться атакой на всю евразийскую сферу.

Президент Трамп, со своей стороны, однозначно высказался: любая нация, нарушающая санкции против Ирана, не будет вести бизнес с США. Но коммерческое сотрудничество Китая с Ираном открыто и прозрачно, разумно, справедливо и законно, не нарушая никаких резолюций Совета Безопасности ООН. Китай не только продолжит, но и увеличит закупки иранской нефти и газа. Китайский автопром - в настоящее время с 10\% иранского рынка - просто возьмет верх по мере ухода французских карцеров. Китайские компании уже несут ответственность за 50\% автозапчастей, ввозимых в Иран.

Россия обязалась инвестировать в иранскую 
нефть и природный газ целых 50 миллиардов долларов. Москва очень хорошо знает о следующем возможном шаге администрации Трампа: введение санкций против российских компаний, инвестирующих в Иран.

Вашингтон просто не может «не вести дела» с Китаем. Вся оборонная промышленность США зависит от Китая по редко земельным материалам. С 1980-х годов американские транснациональные корпорации создали свои экспортные цепочки поставок в Китае при непосредственном содействии правительства США.

Риски ЕС, связанные с развитием интеграционных процессов между Ираном и ЕАЭС следующие:

Во-первых, ЕС рассматривает ЕАЭС как своего конкурента на востоке.

Во-вторых все соглашения с Ираном влекут за собой определенные политические риски. В сентябре 2019 года США ввели санкции в отношении Центрального банка Ирана и 25 иранских компаний. Соединенные Штаты также требуют, чтобы их союзники и все мировое сообщество присоединились к этим санкциям. Скорее всего, санкции против Тегерана продолжат расширять- ся, а американцы довели этот механизм почти до совершенства, отработав и продолжая в ряде вопросов отрабатывать его на том же Иране. На самом деле, хотя некоторые санкции все еще действуют, но та же Европа, не говоря уже о Китае, наращивает торгово-экономическое сотрудничество с Ираном. Таким образом, товарооборот 28 государств - членов ЕС с Исламской Республикой за первые два месяца текущего года составил 3 миллиарда 740 миллионов евро. Стоит отметить, что, например, итальянцы за два месяца 2018 года торговали с иранцами на 844,92 миллиона евро, французы- на 664,84 миллиона, немцы- на 545,83 миллиона, товарооборот между Ираном и Испанией составил 457,65 миллион [4].

В заключении следует отметить, что вступление в силу Временного соглашения, ведущего к образованию зоны свободной торговли между ЕАЭС и Ираном, дало дополнительный стимул к развитию торгово-экономических отношений России и Ирана, но выявленные риски значительно препятствуют расширению взаимовыгодного сотрудничества.

\section{Библиографический список}

1. Бурцева К.Ю.Анализ преимуществ интеграции для Ирана и ЕАЭС/ Экономические науки - М: 2020.№ 7(188). - С. 109-113.

2. Бурцева К.Ю., Зверинская А. А. Экономическая интеграция ЕАЭС со странами, не входящими в экономический союз / Вестник Самарского государственного университета путей сообщения.- Самара: Самарский гос. Ун-т путей сообщения, 2020.- Вып. 2 (48). - С.22-28.

3. Временное соглашение о ЗСТ ЕАЭС - Иран: вызовы и перспективы для евразийского бизнеса. URL: http:// eurasian-studies.org/archives/8772 Дата обращения: 20.04.2020 г.

4. Станет ли Иран конкурентом Казахстана в EAЭС? // URL: https://kapital.kz/economic/68826/stanet-li-irankonkurentom-kazakhstana-v-yeaes.html Дата обращения: 20.04.2020 г.

5. Первые успехи торгового соглашения Ирана с EAЭС URL: https://www.iran.ru/news/economics/114974/ Pervye_uspehi_torgovogo_soglasheniya_Irana_s_EAES Дата обращения: 20.04.2020 г.

6. Подписано Временное соглашение, ведущее к образованию зоны свободной торговли между ЕАЭС и Ираном URL: http://www.eurasiancommission.org/ru/nae/news/Pages/17-05-2018-1.aspx Дата обращения: 30.04.2020г

7. Петров А.М. «КОНТРОЛЬ ЗА ДВИЖЕНИЕМ ДЕБИТОРСКОЙ И КРЕДИТОРСКОЙ ЗАДОЛЖЕННОСТИ» Современный бухучет. 2004. № 9. С. 38.

8. Карпова Т.П., Петров А.М., ГорбатковаГ.А., СамаринаЛ.Б., Дашкина Г.Г., Сидорова М.И., Сабанин Р.Л., СИтникова В.А., ЛистопадЕ.Е. «БУХГАЛТЕРСКИЙ УЧЕТ В СФЕРЕ УСЛУГ» учебнИк дЛя студентов высшего профессионального образования, обучающихся по специальности 080109 «Бухгалтерский учет, анализ и аудит» / Под редакцией М.А.Вахрушиной; Министерство образования и науки Российской Федерации, Федеральное государственное учреждение «Федеральный институт развития образования». Москва, 2011. Сер. Читай

9. Петров А.М., МельниковаЛ.А. «ФОРМИРОВАНИЕ ОТЧЕТНОСТИ В СООТВЕТСТВИИ С ТРЕБОВАНИЯМИ МСФО КАК ОБЪЕКТИВНАЯ НЕОБХОДИМОСТЬ НА СОВРЕМЕННОМ ЭТАПЕ РАЗВИТИЯ ЭКОНОМИКИ РФ» Проблемы современной экономики. 2017. № 2 (62). С. 105-107. 
10. Петров А.М., Коняхин А.Н. «УЧЕТНАЯ ПОЛИТИКА ПРИ ПОДГОТОВКЕ ПЕРВОЙ ОТЧЕТНОСТИ СОГЛАСНО МСФО» Международный бухгалтерский учет. 2013. № 11 (257). С. 2-15.

11. Петров А.М., Лымарь М. П. «СОСТАВ БУХГАЛТЕРСКОЙ ОТЧЕТНОСТИ В РОССИИ И КИТАЕ» МеждУНароДНЫЙ бухгалтерский учет. 2014. № 31 (325). С. 28-37.

12. Петров А.М., Лымарь М.П. «СРАВНИТЕЛЬНАЯ ХАРАКТЕРИСТИКА ОСНОВНЫХ ПОЛОЖЕНИЙ ЗАКОНОВ, РЕГУЛИРУЮЩИХ БУХГАЛТЕРСКИЙ УЧЕТ В КИТАЕ И РОССИИ» МеждународныЙ бухгалтерскиЙ учет. 2013. № 40 (286). C. 52-60.

13. Петров А.М., Лымарь М.П. «СРАВНИТЕЛЬНЫЙ АНАЛИЗ БУХГАЛТЕРСКОГО УЧЕТА АКТИВОВ В РОССИИ И КИТАЕ» Международный бухгалтерский учет. 2014. № 27 (321). С. 34-48.

14. Петров А.М. «ОБЩЕСТВЕННОЕ ПИТАНИЕ 6 в 1: учетная политика, документооборот, калькулирование себестоимости, бухгалтерский учет, налоги, отчетность» / А. М.Петров. Москва, 2011. Сер. Полное руководство бухгалтера 